\title{
Recommendations for bariatric and metabolic surgical operations during the COVID-19 pandemic in Turkey
}

\author{
$\operatorname{Varlık~Erol}^{1}$ (D) , Aziz Sümer²(D), Osman Anıl Savaş²(D), Çağhan Pekşen²(D), Hüseyin Gülay ${ }^{1}$ (D), Recep Aktimur ${ }^{3}$ (D), Mehmet Mahir Özmen ${ }^{4}$ (D) \\ On Behalf of the Initiative of the Board of Directors of the Turkish Society for Metabolic and Bariatric Surgery \\ 1 Department of General Surgery, Baskent University Zubeyde Hanim Practice and Research Center, Izmir, Turkey \\ 2 Department of General Surgery, Istinye University School of Medicine, Istanbul, Turkey \\ ${ }^{3}$ Department of General Surgery, Samsun Liv Hospital, Samsun, Turkey \\ ${ }^{4}$ Department of General Surgery, Istinye University School of Medicine, Istanbul/Liv Hospital Ankara, Ankara, Turkey
}

\begin{abstract}
The world has been struggling with the COVID-19 virus since December 2019. Turkey has also been battling with the virus since March 2019. While struggling with this unknown virus, we have postponed our new bariatric surgeries like most elective surgery. However, curfew and quarantine period (increase in food intake and decreased physical activity) increases risks for morbidity and mortality because of obesity and diabetes. When the pandemic decreases and disappears, many obesity patients will seek treatment for obesity and the workload of surgeons will increase. Before bariatric and metabolic surgery operations, which is the most effective treatment of obesity and related comorbidities, necessary precautions must be determined and implemented to protect patients and healthcare workers before and during surgery. In this review, it was aimed to determine the pre-peri and postoperative periods of bariatric surgical requirements. This review has been written on behalf of the Turkish Society for Metabolic and Bariatric Surgery as an initiative in order to answer some questions about bariatric and metabolic surgery during the COVID-19 pandemic.
\end{abstract}

Keywords: Bariatric and metabolic surgery, COVID-19, coronavirus

Cite this article as: Erol V, Sümer A, Savaş OA, Pekşen $C$ Gülay H, Aktimur R, Özmen MM. Recommendations for bariatric and metabolic surgical operations during the COVID-19 pandemic in Turkey. Turk J Surg 2020; 36 (2): 132-136.

\section{Corresponding Author}

Varlık Erol

E-mail: varlikerol@gmail.com

Received: 16.05 .2020

Accepted: 19.05 .2020

Available Online Date: 20.05 .2020

() Copyright 2020 by Turkish Surgical Society Available online at www.turkjsurg.com

DOI: $10.5578 /$ turkjsurg.4875

\section{Introduction}

Obesity is a public health problem affecting the whole world, lowers the quality of life and is associated with many comorbid diseases such as diabetes, hypertension, hyperlipidemia, obstructive sleep apnea syndrome and degenerative joint diseases. Bariatric surgery is the most effective treatment method that provides intensive weight loss and lowers comorbidities associated with over-weight (1). During the COVID-19 epidemic, which was announced by the World Health Organization as a pandemic in March 2020, new bariatric surgeries, like most elective surgeries, were postponed all over the world because of intraoperative risks for viral contagion among patients and healthcare workers.

However, the curfew and quarantine period (increase in food intake and decreased physical activity) increase risks for morbidity and mortality because of obesity and diabetes. On the other hand, obesity itself increases the risk of various diseases, including type II diabetes, hypertension, dyslipidemia, non-alcoholic fatty liver disease, cardiovascular and cerebrovascular diseases, various type of cancers, osteoarthritis, and nowadays the COVID-19 infection. All of the mentioned diseases also reduce quality of life, increase psychosocial dysfunction and obesity-related morbidity and mortality. Despite COVID-19, obesity and related comorbidities have reduced life expectancy by 5-20 years (2). In addition to the well-known indications for bariatric surgery, Diabetes Surgery Summit (DSS) guidelines recommend the consideration of metabolic surgery for appropriate candidates, including patients who has un-controlled type II diabetes with class I obesity (3).

Due to the increasing number of COVID-19 patients, patient beds, ventilators and intensive care units have been reserved for these patients. At the same time, when the pandemic decreases and disappears, many obesity patients will seek treatment for obesity, and the workload of surgeons will increase. However, the 
clinical presentation and outcomes of surgical patients during the COVID-19 outbreak have not been clearly characterized (4). Before starting operations, some questions such as 'which operation is the most effective treatment of obesity and related comorbidities, what kind of precautions must be determined and implemented to protect patients and healthcare workers before and during surgery' should be answered. According to the severity of the diseases that require bariatric and metabolic surgery, clinicians and health care authority should ensure that these operations are not further delayed because of increased morbidity and mortality (5).

This review has been written on behalf of the Turkish Society for Metabolic and Bariatric Surgery as an initiative in order to answer some questions about bariatric and metabolic surgery during COVID-19 pandemic.

\section{Pre-operative Patient Preparation}

Due to comorbidities and risks of morbidity, we should be more careful in preparing obesity patients for bariatric operation during the outbreak, who have undergone a more detailed pre-operative preparation process than other surgical patients before the pandemic. The patients who undergo surgery are required to meet the following criteria: BMI (body mass index) between $35-40 \mathrm{~kg} / \mathrm{m}^{2}$ with obesity-related co-morbidities or BMI $\geq 40 \mathrm{~kg} / \mathrm{m}^{2}$ with or without obesity related co-morbidities and BMI 30 to $34.9 \mathrm{~kg} / \mathrm{m}^{2}$ with metabolic syndrome or diabetes that is uncontrolled with medical therapy.

Before all preparations, the patient's detailed medical history in terms of covid-19 disease should be taken and evaluated by the pulmonologist in terms of COVID-19 with the help of blood tests and thoracic computerized tomography images (Figure 1). While non-serious symptoms can emerge in nearly half of the patients infected with COVID-19, the other half can show primary symptoms such as fatigue, dry cough, myalgia and dyspnea (6). The most common laboratory findings are leukopenia and lymphopenia. Lactate dehydrogenase and creatinine kinase elevation may also be seen. Half of the patients may have abnormal liver function tests like alanine aminotransferase (ALT) or aspartate aminotransferase (AST) elevation. Although normal serum procalcitonin levels are seen in the majority of patients, C-reactive protein (CRP) levels have been found above the normal range. D-Dimer has been determined high in one third of the patients $(7,8)$. If available, surgical patients should be tested pre-operatively for COVID-19.

If surgery is considered, screening and precaution measures should be taken strictly just like during the pandemic. Safety of the patients and healthcare professionals is a top priority in all clinical practices. The number of operations should be limited.

Preoperative evaluation should be made by a multidisciplinary team consisting of endocrinologists, dieticians, psychologists, pulmonologists, cardiologists, anesthesiologists and the sur- geon. An informed consent form must be obtained from all bariatric and metabolic surgery candidates regarding operation in the COVID-19 pandemic and its predicted risks, as recommended other gastrointestinal operations (9). Additionally, a COVID informed patient program could be planned to inform the patients about potential complications and avoiding strategies in the post-operative period (10).

A detailed past medical and surgical history should be taken, and anthropometric measurements should be made. Laboratory workup should include a comprehensive metabolic panel, complete blood count and CRP, iron, vitamins, and folate, hemoglobin A1C, and a coagulation panel.

An abdominal ultrasonography should be performed for the screening of cholelithiasis and intra-abdominal mass (adrenal gland, liver, etc.). Esophagogastroduodenoscopy can be applied if the patient has upper digestive symptoms. The American Society of Metabolic and Bariatric Surgery advises the use of endoscopy only for patients with significant gastrointestinal symptoms $(11,12)$.

The patient should also complete screening for cardiac diseases such as ischemic heart disease, systemic and pulmonary hypertension, right or left ventricular failure signs etc.

Psychologic and behavioral evaluation, nutritional evaluation, medical clearance, and anesthesiology evaluation are mandatory during the pre-operative work-up of the patient undergoing weight loss surgery.

If the surgery is delayed, glycemic control should be carefully optimized in patients awaiting metabolic surgery for type II diabetes. In addition, dietary or pharmacological interventions for weight control in patients who face prolonged waiting times for bariatric surgery might become necessary (5).

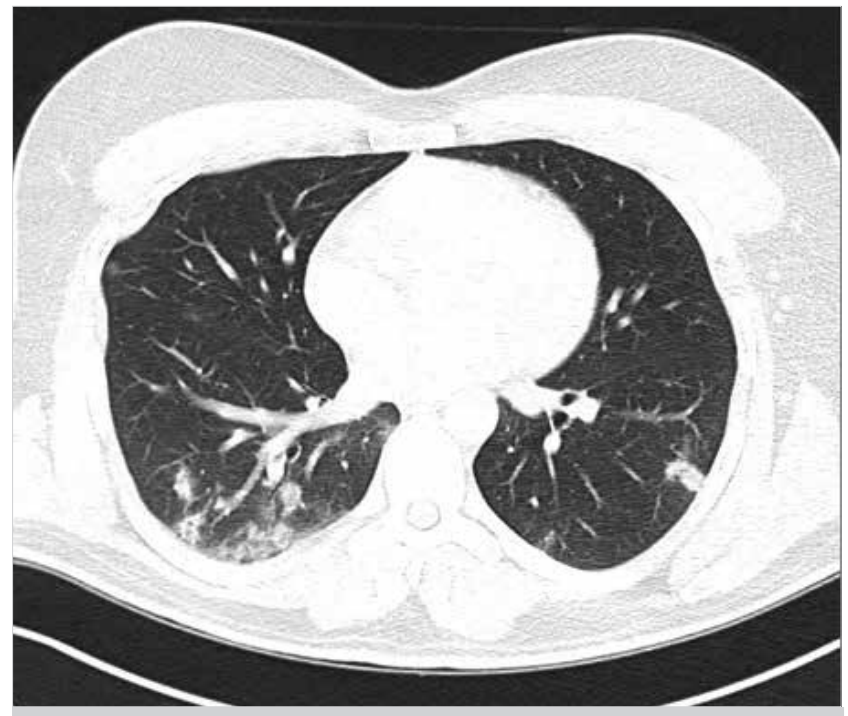

Figure 1. Thorax tomography image of a patient diagnosed with COVID-19. 
DSS recommendations for the management of surgical candidates for bariatric and metabolic surgery during and after COVID-19 pandemic suggests categorization for elective surgery into urgent, semi-urgent, or non-urgent. Urgent elective surgery is required within 30 days for patients, whose conditions might deteriorate quickly. Semi-urgent elective surgery defined as if it delayed beyond 3 months, the patients could suffer from severe pain or dysfunction. Non-urgent elective surgery is planned for patient conditions that are unlikely to cause harm if treated within 1 year (5) (Table 1).

\section{Peri-operative Period (Operating Room)}

The operating room is one of the places where attention should be intensified to protect both patients and healthcare professionals during the COVID-19 outbreak. It is even more important to be protected from COVID-19 when performing elective surgeries that are relatively less urgent, such as obesity surgery. All staff must be trained to use personnel protection equipment (PPE) including masks (level 2 or 3 filtering face piece (FFP) depending on the aerosol-generating risk level), eye protection, double non-sterile gloves, gowns, suites, caps, and socks (13) (Figure 2). The number of staff in the operating room should be kept as low as possible, and staff's travel between operating rooms should be prevented unless it is necessary and all doors must be kept closed (14).

During patient transport, in order to minimize the possibility of encountering the virus, a shortest possible route should be defined in advance and kept away from other patients and people in general within the hospital.
Although negative pressure operation rooms minimize the risk of infection spread, operating rooms generally have positive pressure air circulation (15). High frequency of air exchanges (25 cycles/h) effectively reduces viral load within the operation room (16).

All equipment required for surgery should be available in the operating room, thus minimizing staff entry and exit during surgery. Use of non-disposable materials should be avoided, unless essential. The operation team should arrive in the room on time and should not leave the operating room unless the operation ends to prevent unnecessary entry and exit.

There is little evidence of relative risks of Minimal Invasive Surgery (MIS) compared to the conventional open approach. The risk and benefit of laparoscopic surgery remain favorable for patients and should be preferred to open surgery (5). However, since obesity surgery is usually performed laparoscopically, protective measures must be taken due to the possibility of viral contamination during surgery.

Although some studies have claimed that laparoscopy can lead to aerosolization of blood-borne viruses, there is no evidenced base proof support that COVID-19 has spread in this way and laparoscopic procedures should not be performed $(17,18)$. Nevertheless, it should be kept in mind that the coronavirus may have similar aerosolization properties, and the use of devices that can filter the emitted $\mathrm{CO}_{2}$ for aerosolized particles in laparoscopic procedures is useful. If possible, it would be safer to perform intubation and extubation in a negative pressure room.

Table 1. Categories of access to bariatric and metabolic surgery*

\section{Urgent access: surgery within $\mathbf{3 0}$ days}

Patient's condition is associated with one of the following:

- Conditions with potential to deteriorate quickly

- Severe symptoms or dysfunction

- Examples include severe dysphagia or vomiting from anastomotic stenosis, symptomatic internal hernia, severe nutritional deficiencies, or acute band-related complications

\section{Expedited access: surgery within $\mathbf{9 0}$ days}

Patient's conditions are not likely to deteriorate quickly but are associated with one of the following:

- Substantial risk of morbidity or mortality

- Reasonable risk of harm or reduced efficacy of treatment if surgery is delayed beyond 90 days

- Complex medical regimens or insulin requirement

- Weight loss, metabolic improvement, or both, are required to allow other

time-sensitive treatments (e.g., organ transplants or orthopaedic surgery)

\section{Standard access: surgery after 90 days}

- Patient's conditions are unlikely to deteriorate within 6 months

- Only mild dysfunction or symptoms

- Delaying surgical treatment beyond 90 days is unlikely to significantly reduce effectiveness of surgery

* Retrieved from source 5 . 


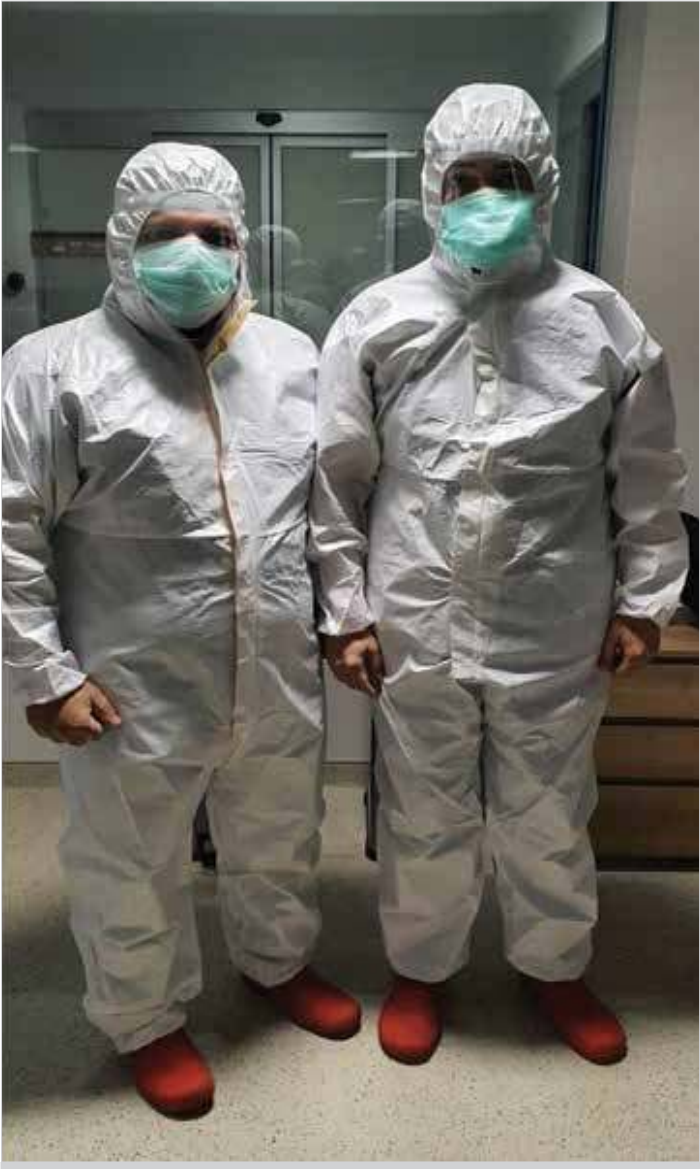

Figure 2. Personnel protective equipment.

During the laparoscopic surgery, the incisions made for the ports should be as large as the instruments can pass and are small enough not to allow gas leakage. If the first trocar is placed by open Hasson technique, the purse string suture should be made around the first trocar in order to prevent gas leak. Intra-abdominal $\mathrm{CO}_{2}$ insufflation pressure must be kept to a minimum level. Ultrafiltration (smoke evacuation system or filtration) should be used if it is available. Filtration system should be used to safely discharge intra-abdominal gas.

\section{Post-operative Period}

In order to reduce hospital and patient contamination in the postoperative period, the primary priority should be keeping patients' hospital stay short. Enhanced recovery after surgery (ERAS) protocol can also be applied for this purpose (19). The number of visitors should be kept to a minimum during the time of hospital stay. It should be ensured that the nurses and staff who continue the treatment of the patient are trained on contamination and have taken all necessary precautions.

\section{Conclusion}

In the period when the whole world has been struggling with the COVID-19 pandemic and the speed of outbreak spread is the fastest, bariatric surgeries are unfortunately postponed. However, in case of long-term delay of these surgeries, the possibility of morbidities regarding morbid obesity and related diseases and their negative effects on the country's economy should not be ignored. Therefore, with the onset of the normalization process, bariatric surgery will also be started with correct patient selection and appropriate pre-intra and postoperative preparations. An informed consent form must be obtained from all obesity patients regarding COVID-19 infection and its predicted risks. The most important issue here is that the entire team that will contact the patient before, during and after the surgery is trained and takes all necessary measures to reduce contamination.

This review has been written on behalf of the Turkish Society for Metabolic and Bariatric Surgery in order to answer some questions about bariatric and metabolic surgery during COVID-19 pandemic.

Conflict of Interest: No conflict of interest was declared by the authors.

Financial Disclosure: The authors declared that this study has received no financial support.

\section{REFERENCES}

1. Gastrointestinal surgery for severe obesity. Proceedings of a National Institutes of Health Consensus Development Conference. March 2527, 1991, Bethesda, MD. In: American Journal of Clinical Nutrition. 1992. [CrossRef]

2. Fontaine KR, Redden DT, Wang C, Westfall AO, Allison DB. Years of life lost due to obesity. J Am Med Assoc 2003; 289(2): 187-93. [CrossRef]

3. Rubino F, Nathan DM, Eckel RH, Schauer PR, Alberti KGMM, Zimmet $P Z$, et al. Metabolic surgery in the treatment algorithm for type $2 \mathrm{di}$ abetes: A joint statement by international diabetes organizations. Diabetes Care 2016; 39(6): 861-77. [CrossRef]

4. Aminian A, Safari S, Razeghian-Jahromi A, Ghorbani M, Delaney CP. COVID-19 outbreak and surgical practice: unexpected fatality in perioperative period. Ann Surg 2020 Mar 26. doi: 10.1097/ SLA.0000000000003925. [Epub ahead of print]. [CrossRef]

5. Rubino F, Cohen RV, Mingrone G, le Roux CW, Mechanick Jl, Arterburn $D E$, et al. Bariatric and metabolic surgery during and after the COVID-19 pandemic: DSS recommendations for management of surgical candidates and postoperative patients and prioritisation of access to surgery. lancet Diabetes Endocrinol [Internet] 2020 May 7 [cited 2020 May 16]; Available from: http://www.ncbi.n/m.nih.gov/ pubmed/32386567. [CrossRef]

6. Guan WJ, Ni ZY, Hu Y, Liang WH, Ou CQ, He JX, et al. Clinical characteristics of coronavirus disease 2019 in China. N Engl J Med 2020 Apr 30. [CrossRef]

7. Karaca AS, Ozmen MM, Uçar AD, Yasti AÇ, Demirer S. General surgery operating room practice in patients with COVID-19. Turk J Surg 2020; 36(1): I-V. [CrossRef]

8. Bhangu A, Lawani I, Ng-Kamstra JS, Wang Y, Chan A, Futaba K, et al. Global guidance for surgical care during the COVID-19 pandemic. Br J Surg 2020 Apr 15. doi: 10.1002/bjs.11646. [Epub ahead of print]. [CrossRef] 
9. Colakoglu MK, Oter V, Bostancı EB, Ozmen MM, Saribeyoglu K. Surgical management of digestive system cancers during the coronavirus disease 2019 pandemic: review of general suggestions. Turk J Surg 2020;36. doi: 10.5578/turkjsurg.4812. [CrossRef]

10. American College of Surgeons. American College of Surgeons PostCOVID-19 Readiness Checklist for Resuming Surgery. https://www. facs.org/covid-19/checklist\#refi. 2020. [CrossRef]

11. Thorell A, MacCormick AD, Awad S, Reynolds N, Roulin D, Demartines $N$, et al. Guidelines for perioperative care in bariatric surgery: enhanced recovery after surgery (ERASs rociety Recommendations. World Surg 2016; 40(9): 2065-83. doi: 10.1007/s00268-016-3492-3. [CrossRef]

12. Parrott J, Frank L, Rabena R, Craggs-Dino L, Isom KA, Greiman L. American society for metabolic and bariatric surgery integrated health nutritional guidelines for the surgical weight loss patient 2016 update: micro. Surg Obes Relat Dis [Internet] 2017 May 1 [cited 2020 May 15]; 13(5): 727-41. Available from: http://dx.doi.org/10.1016/j. soard.2016.12.018 [CrossRef]

13. Coccolini F, Perrone G, Chiarugi M, Di Marzo F, Ansaloni L, Scandroglio I, et al. Surgery in COVID-19 patients: operational directives. World J Emerg Surg 2020 Apr 7; 15(1): 25. doi: 10.1186/s13017-020-00307-2. [CrossRef]

14. Shabbir A, Menon RK, Somani J, So JBY, Ozmen M, Chiu PWY, et al. ELSA recommendations for minimally invasive surgery during a community spread pandemic: a centered approach in Asia from widespread to recovery phases. Surg Endosc [Internet] 2020 May 11 [cited 2020 May 16]; Available from: http://www.ncbi.nlm.nih.gov/ pubmed/32394175. [CrossRef]
15. Forrester JD, Nassar AK, Maggio PM, Hawn MT. Precautions for operating room team members during the COVID-19 pandemic. J Am Coll Surg 2020 Apr 2. pii: S1072-7515(20)30303-3. doi: 10.1016/j.jamcollsurg.2020.03.030. [Epub ahead of print]. [CrossRef]

16. Wong J, Goh QY, Tan Z, Lie SA, Tay YC, Ng SY, et al. Preparing for a COVID-19 pandemic: a review of operating room outbreak response measures in a large tertiary hospital in Singapore. Can J Anaesth 2020; 67(6): 732-45. doi: 10.1007/s12630-020-01620-9. Epub 2020 Mar 11. [CrossRef]

17. Kwak HD, Kim SH, Seo YS, Song KJ. Detecting hepatitis B virus in surgical smoke emitted during laparoscopic surgery. Occup Environ Med 2016; 73(12): 857-63. [CrossRef]

18. Alp E, Bijl D, Bleichrodt RP, Hansson B, Voss A. Surgical smoke and infection control. J Hosp Infect [Internet]. 2006 Jan [cited 2020 May 15]; 62(1): 1-5. Available from: http://www.ncbi.n/m.nih.gov/pubmed/16002179. [CrossRef]

19. Aktimur R, Kirkil C, Yildirim K, Kutluer N. Enhanced recovery after surgery (ERAS) in one-anastomosis gastric bypass surgery: a matchedcohort study. Surg Obes Relat Dis 2018; 14(12): 1850-6. [CrossRef]

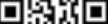 \\ DERLEME-ÖZET
}

Turk J Surg 2020; 36 (2): 132-136

\section{Türkiye'de COVID-19 pandemisi sürecinde bariatrik ve metabolik cerrahi operasyonlar için öneriler}

\author{
Varlık Erol ${ }^{1}$, Aziz Sümer ${ }^{2}$, Osman Anıl Savaş² , Çağhan Pekşen² ${ }^{2}$ Hüseyin Gülay ${ }^{1}$, Recep Aktimur ${ }^{3}$, Mehmet Mahir Özmen ${ }^{4}$ \\ Türk Metabolik ve Bariatrik Cerrahi Derneği Yönetim Kurulu Girişimi Adına \\ 1 Başkent Üniversitesi Zübeyde Hanım Uygulama ve Araştırma Merkezi, Genel Cerrahi Bölümü, İzmir, Türkiye \\ ${ }^{2}$ Istinye Üniversitesi Tıp Fakültesi, Genel Cerrahi Anabilim Dalı, İstanbul, Türkiye \\ ${ }^{3}$ Samsun Liv Hospital, Genel Cerrahi Bölümü, Samsun, Türkiye \\ ${ }^{4}$ Isstinye Üniversitesi Tıp Fakültesi, Genel Cerrahi Anabilim Dalı, İstanbul/Liv Hospital Ankara, Genel Cerrahi Bölümü, Ankara, Türkiye
}

\section{ÖZET}

Dünya Aralık 2019'dan beri COVID-19 virüsü ile mücadele ediyor. Türkiye de Mart 2019'dan beri mücadele ediyor. Bu bilinmeyen virüsle mücadele ederken, diğer elektif cerrahi operasyonlar gibi yeni bariatrik ameliyatlarımızı da erteledik. Bununla birlikte, sokağa çıkma yasağı ve karantina süresi (gıda alımındaki artış ve fiziksel aktivitenin azalması) obezite ve diyabet nedeniyle morbidite ve mortalite risklerini arttırmaktadır. Pandemi azaldığında ve kaybolduğunda birçok obezite hastası, obezite için tedavi arayışına girecek ve cerrahların iş̧ yükü artacaktır. Obezite ve ilgili komorbiditelerin en etkili tedavisi olan bariatrik ve metabolik cerrahi operasyonlarına başlamadan önce, ameliyat öncesi ve sırasında hastaları ve sağlık çalışanlarını korumak için gerekli önlemler belirlenmeli ve uygulanmalıdır. Bu derlemede, bariatrik cerrahi gerekliliklerinin ameliyat öncesi ve sonrası dönemlerinin belirlenmesi amaçlanmıştır. Bu derleme, COVID-19 salgını sırasında bariatrik ve metabolik cerrahi ile ilgili bazı soruları cevaplamak amacıyla, Türk Bariatrik ve Metabolik Cerrahi Derneği insiyatifinde yazılmıştır.

Anahtar Kelimeler: Bariatrik ve metabolik cerrahi, COVID-19, koronavirüs

Doi: $10.5578 /$ turkjsurg.4875 